\title{
SOCIAL SECURITY REFORM AND \\ INTERGENERATIONAL TRADE: IS THERE SCOPE FOR A PARETO-IMPROVEMENT?
}

\author{
MARKO KÖTHENBÜRGER \\ PANU POUTVAARA
}

CESIFO WORKING PAPER NO. 795

CATEGORY 1: PUBLIC FinANCE

OCTOBER 2002

\footnotetext{
An electronic version of the paper may be downloaded

- from the SSRN website: www.SSRN.com

- from the CESifo website: www.CESifo.de
} 


\title{
SOCIAL SECURITY REFORM AND INTERGENERATIONAL TRADE: IS THERE SCOPE FOR A PARETO-IMPROVEMENT?
}

\begin{abstract}
In earlier literature, the suggested Pareto improvements in pay-as-you-go (PAYG) systems have relied on the presence of externalities or the possibility of intragenerational redistribution. We show that neither assumption is necessary in an economy with intergenerational trade in a fixed factor of production, here labeled as land. Reducing the social security tax rate encourages investment in complementary human capital. Future efficiency gains accruing to land are capitalized in its value which compensates the landowning pensioners for reduced benefits. We also explain why the PAYG system may have lost its appeal even for pensioners after its introduction.
\end{abstract}

JEL Classification: H55, H21, I38.

Keywords: social security reform, fixed factor, pay-as-you-go system, capital gains taxation.

Marko Köthenbürger

Cesifo (University of Munich \& Ifo Institute)

Poschingerstrasse 5

81679 Munich

Germany

koethenbuerger@cesifo.de
Panu Poutvaara

Centre for Economic and Business Research

Langelinie Alle 17

DK-2100 Copenhagen

Denmark

panu.poutvaara@cebr.dk

A previous version of the paper circulated under the title "Social Security Reform with a Fixed Factor". We are grateful for useful comments from Ulrich Hange, Roisin Hearn, Katarina Keller, Etienne Lehmann, Ismo Risku, Hans-Werner Sinn, Bas van Groezen, Harrie Verbon and other participants in seminars at CES in June 2001 and VATT in September 2001, the European Public Choice Society Annual Meeting in Belgirate, Italy, April 4-7, 2002, the Spring Meeting of Young Economists in Paris, April 18-20, 2002, the EEA Annual Meeting in Venice, Italy, August 22-24, 2002, and the IIPF Annual Conference in Helsinki, Finland, August 26-29, 2002. Earlier versions of the paper were written while Poutvaara was employed first at the Department of Economics, University of Helsinki, and then at the Government Institute for Economic Research (VATT). Financial support from the Danish Ministry of Economic and Business Affairs is gratefully acknowledged, while none of our employers are responsible for our conclusions. 


\section{Introduction}

In most, if not all, Western countries participation in the pay-as-you-go (PAYG) social security system does not seem attractive for the current younger generations. The expected rate of return on social security contributions is considerably lower than the expected rate of return on financial investments. Lower and even negative population growth only aggravates the burden that a PAYG system imposes on younger generations. This has stimulated a considerable interest in a social security reform in which the PAYG system would be replaced at least partially by a funded component taking advantage of a higher market rate of return.

The existence of a higher rate of return in a fully-funded system may suggest that a Pareto-improving transition to a fully-funded system is possible. Gains in pension claims of future generations are expected to be sufficiently high to compensate the pensioners of the transition generation for the reduction in their benefits. Though shaping the political and academic discussion on pension reform ${ }^{1}$, this argument lacks a general theoretical foundation. According to Fenge (1995) and Brunner (1996), a Pareto-improving transition is not feasible once an intragenerationally-fair PAYG system $^{2}$ is in place. If the elderly are compensated for the lost benefits using public debt, then the implicit tax imposed by the PAYG system is converted into an explicit tax levied to service public debt. The discounted value of the tax burden, however, remains unchanged, indicating that the intertemporal efficiency gains are neutralized by higher distortionary explicit taxes on future generations (Sinn, 2000). Notably, the "arithmetic" of PAYG reform holds independently of the magnitude of pre-existing general wage taxes. ${ }^{3}$

In this paper, we introduce a different mechanism through which the elderly participate

\footnotetext{
${ }^{1}$ Most prominently, Feldstein (1996) advocates replacing PAYG system by a funded one based on this argument. In contrast, see Diamond (1996) for a critical evaluation of the rate-of-return argument in restructuring social security.

${ }^{2}$ A PAYG system is intragenerationally fair if contributions are not used for intragenerational income redistribution. Such a system imposes an implicit tax equal for all members of a generation.

${ }^{3}$ The Pareto-efficiency of the PAYG system has first been demonstrated in Breyer (1989) and Verbon (1989). In contrast to Fenge and Brunner, Breyer and Verbon assume an exogenous labor supply and a PAYG system with lump-sum contributions and pension benefits. Besides the explanation presented above, the Pareto-efficiency of the PAYG system in Breyer and Verbon can be explained by invoking the Second Welfare Theorem. Since the initial allocation is undistorted and a reform of the PAYG system is equivalent to a lump-sum redistribution of incomes between generations, no reform can yield a Pareto-improvement.
} 
in the future efficiency gains created by a decrease in the PAYG tax rate. This mechanism consists of voluntary market transactions in the fixed factor, here labeled as land. Land should be interpreted broadly to include all factors of production capitalized in the stock market. The presence of a fixed factor has two implications in our model. First, the economy is dynamically efficient, i.e. the interest rate exceeds the output growth rate (Homburg, 1991 and Rhee, 1991). Second, that part of the future efficiency gains which accrues to land is immediately capitalized in its current value. If sufficiently high, the increase in land value outweighs the loss from cutting social security benefits for the old land owners. The empirical relevance of our analysis derives from two dramatic changes in U.S. retirement saving during the last two decades. These are the transition from defined benefit plans to defined contribution plans, and the associated huge increase in the value of pension assets. Poterba et al. (2001) report that in 198059 percent of private retirement savings were in employer-based defined benefit plans while currently 85 percent are to defined contribution plans in which individuals decide on the level and investment of their contributions. At the same time, the ratio of all private retirement assets to wage and salary earnings quadrupled. This suggests that increased private asset wealth has moved the interests of retirees and workers near retirement closer to those of the younger generations concerning reduction in PAYG tax rates.

We analyze an overlapping generations model in which each cohort lives for three periods. During the first period of life, the members of the cohort invest privately in education. In the second period of life, they supply labor services equal to their human capital to production and purchase land from the older generation. Social security contributions are collected. During the third period of life, they receive social security benefits (indexed to past contributions) as retirees and land rents as land owners, as well as sell the land to the next generation.

In addition to the presence of the capitalization effect as a compensation mechanism, our model differs from the existing literature in several important respects. First of all, there is only intergenerational redistribution through social security. ${ }^{4}$ Identical for all

\footnotetext{
${ }^{4}$ Any PAYG system can be divided into two parts; one implementing intergenerational redistribution and the other intragenerational redistribution. We analyze a system which redistributes only intergenerationally since this part is inherently related to a PAYG system. Inefficiencies in the intragenerational tax-transfer scheme can be addressed without affecting the "core" of the PAYG system, namely intergenerational redistribution.
} 
individuals, pension benefits are a constant fraction of former contributions. ${ }^{5}$ Secondly, there are no externalities in our model. Thirdly, we do not allow for distortions arising from early retirement provisions. Distortions additional to intergenerational redistribution prove to be critical sources of welfare gains in existing literature. ${ }^{6}$ In that respect, we adopt a restrictive framework - importantly - in which existence of a Pareto-improving pension reform has not yet been proven.

Laitner (2000) analyzes social security reform when future productivity gains are incorporated into stock prices. Firms have two assets: reproducible physical capital and capitalized value of patents. Contrary to our analysis, Laitner does not consider the potential of a Pareto-improving transition. Since labor supply is fixed and there is no human capital formation, PAYG contributions and benefits are lump-sum. In this framework, the PAYG system is Pareto-efficient, clearly leaving no scope for analyzing the feasibility of a Pareto-improving social security reform. ${ }^{7}$ Similarly, İmrohoroğlu et al. (1999) consider pension reform in an economy with land. Assuming inelastic labor supply, they analyze the trade-off between the risk-sharing benefit (due to incomplete capital and insurance markets) and the negative effects on capital accumulation of the PAYG system. They argue that steady state generations are still better off when abolishing PAYG system. However, as a caveat, even in the presence of perfect markets, which compensate for missing risk-sharing under a fully-funded system, a Pareto-improvement cannot be obtained

\footnotetext{
${ }^{5}$ This corresponds to social security systems in Austria, Finland, Germany, Italy and Portugal, in which the difference in the gross replacement rate between high-income and low-income earners is at most 3 percentage points. In the U.S., the gross replacement rate decreases from 71 percent for those with a final salary of $\$ 20,000$ to 45 percent for those with a final salary of $\$ 50,000$ (Miles and Timmermann 1999).

${ }^{6}$ Homburg (1990), Feldstein and Samwick (1998), Kotlikoff (1998), and Cooley and Soares (1999b) suggest a Pareto-improving reform analyzing a PAYG system which allows for intragenerational redistribution. Their analysis is consistent with the theoretical result in Fenge (1995) since the simulated PAYG systems do not exhibit intragenerational fairness. In this case pension benefits are only loosely linked to contributions making the system highly distortionary. The distortion created by physical capital externalities in Belan et al. (1998) and Corsetti and Schmidt-Hebbe (1997) can be addressed by a savings subsidy without reforming the social security system (Sinn, 2000). Analogously, efficient retirement decisions can separately be achieved by introducing actuarial fairness at the margin (Cremer and Pestieau, 2002).

${ }^{7}$ Closely related to Laitner, Roberts (2001) considers a closed economy with exogenous labor supply where a fixed factor enters production. The paper claims to have established the existence of a Paretoimproving social security reform, though the framework adopted does not allow for it (see the Second Welfare Theorem). Particularly, the reform suggested in Roberts' paper violates the resource constraint for a closed economy. We became aware of each other's papers in September 2002.
} 
for the reasons given above. Therefore, the transition generation problem is not solved therein.

Intergenerational trade in land has important implications for the political process. Due to population aging, pensioners receive a larger representation in the political process which tends to preserve a generous pension system rather than allowing for a restrictive pension reform (Boadway and Wildasin, 1989). Cooley and Soares (1999a) argue that the interests of the working generation near retirement and pensioners are sufficiently closely aligned which gives rise to a political majority against privatization of social security. Hansson and Stuart (1989) even argue that social security is an implicit contract among living generations in which the old have veto power. Pension reform thus requires an intergenerational consensus. As shown in this paper, intergenerational trade is one mechanism to moderate if not resolve intergenerational conflict among living generations and, interestingly, to indirectly represent future generations' interests in the contemporary political process.

We also suggest alternative reasons for why a currently inefficient social security system could have been installed in the first place. Typically, social security systems have been introduced and increased in the 19th century and early 20th century, when other public expenditures were much smaller. Our model suggests that an increase in the wage tax rate collected to finance other public expenditures could alone render a social security system, which initially benefited the elderly, so costly that currently even they might benefit from its partial or even full dismantling. Also, changes in the demographics, productivity growth or interest rates may render a system previously supported at least by the elderly unattractive also for them, opening up the possibility for an intergenerational Pareto improvement.

Our paper is organized as follows. In Section 2, we present the model of an economy with pay-as-you-go social security. In Section 3, we introduce social security reform and consider the potential for Pareto-improvements. In Section 4, we present possible explanations for the rise and fall of the PAYG system. Section 5 concludes. 


\section{Model}

\subsection{Production}

Production in any given period $t$ depends on the available technology and factors of production. We assume that there are three factors of production: physical capital, human capital and land. The amount of land is normalized to unity. Aggregate human and physical capital in the economy in period $t$ is denoted by $H_{t}$ and $K_{t}$, respectively. The production function is Cobb-Douglas with $A_{t}$ reflecting the state of technology in period $t$. Thus, ${ }^{8}$

$$
Y_{t}=A_{t} H_{t}^{\alpha_{H}} K_{t}^{\alpha_{K}}
$$

where $0<\alpha_{H}, \alpha_{K}<1$ and $\alpha_{H}+\alpha_{K}<1$. All markets are competitive, and therefore profit maximization implies that:

$$
w_{t}=\alpha_{H} A_{t} H_{t}^{\alpha_{H}-1} K_{t}^{\alpha_{K}}, \quad r=\alpha_{K} A_{t} H_{t}^{\alpha_{H}} K_{t}^{\alpha_{K}-1}
$$

and

$$
R_{t}=\left(1-\alpha_{H}-\alpha_{K}\right) A_{t} H_{t}^{\alpha_{H}} K_{t}^{\alpha_{K}}
$$

$w_{t}$ denotes the wage rate per unit of human capital in period $t, r$ is the interest rate and $R_{t}$ stands for the land rent in period $t$. The production function for human capital is

$$
h_{t}=e_{t-1}^{\beta},
$$

where $0<\beta<1$. Individual human capital stock in period $t$ depends on investment in education in the former period, $e_{t-1}$. The marginal productivity of education is diminishing and the unit cost of education is 1 . The costs of education should be interpreted broadly in the sense that they might also include the monetarized value of effort cost. We do not consider opportunity costs explicitly, as those are effectively tax deductible with proportional taxation. The aggregate stock of human capital is the product of the stock per worker and the number of workers, $N_{t}$,

$$
H_{t}=N_{t} h_{t}
$$

\footnotetext{
${ }^{8}$ We directly introduce a parameterized version of the economy needed for simulations in Section 3 . This modelling approach is without loss of generality. All qualitative results derived in Sections 3 and 4 carry over to a neoclassical production function for output and human capital.
} 
We assume a constant population growth rate, so that the size of the cohort working in period $t$ is given by

$$
N_{t}=N_{0}(1+n)^{t}
$$

where $n \geqq 0$ is the growth rate of the population per cohort. While our model could be solved also for $n<0$, we restrict our attention to non-negative growth rates, as negative growth rates would imply the population of zero in the limit. Production depends also on technology parameter

$$
A_{t}=A_{0}(1+g)^{t}
$$

where $g \geqq 0$ denotes technological progress. Since the pension system entails no intragenerational redistribution, we assume identical individuals. ${ }^{9}$ Furthermore, there is no uncertainty.

Individuals can invest their savings in the international capital market or the national land market. ${ }^{10}$ By arbitrage, land value in period $t$ is given by ${ }^{11}$

$$
(1+r) V_{t}=R_{t+1}+V_{t+1}
$$

Recursive substitution yields:

$$
V_{t}=\sum_{i=1}^{\infty} \frac{R_{t+i}}{(1+r)^{i}}
$$

\subsection{Individual Maximization}

We assume a well-behaved utility function defined over private and public consumption. All individuals can save and borrow freely at the exogenous interest rate $r$, determined by the international capital market, to smooth their consumption over their lifetime.

\footnotetext{
${ }^{9}$ The Appendix contains an extension to the case of individual ability differences.

${ }^{10}$ Even with integrated capital markets, full domestic land ownership could be guaranteed by foreigners facing a small transaction cost if they were to buy domestic land, whereas there would be no transaction cost in an international loan market. Transaction cost in foreign land acquisition might arise due to asymmetric information on the part of investors (Gordon and Bovenberg, 1996) which tends to play a diminished role in international loan markets.

${ }^{11}$ Though economic agents have a finite horizon, speculative bubbles are not considered as a component of the land price. Given the presence of a fixed factor, the economy turns out to be dynamically efficient which rules out the existence of bubbles (Tirole, 1985).
} 


\begin{tabular}{|c|c|c|c|c|}
\hline 1st period & \multicolumn{2}{|c|}{ 2nd period } & \multicolumn{2}{|c|}{ 3rd period } \\
\hline $\begin{array}{l}\text { invests in } \\
\text { human } \\
\text { capital }\end{array}$ & $\begin{array}{l}\text { works and } \\
\text { receives } \\
\text { net-of tax } \\
\text { wage }\end{array}$ & $\begin{array}{l}\text { buys } \\
\text { land }\end{array}$ & $\begin{array}{l}\text { receives } \\
\text { land rent } \\
\text { and pension } \\
\text { benefits }\end{array}$ & $\begin{array}{l}\text { sells } \\
\text { land }\end{array}$ \\
\hline
\end{tabular}

Figure 1: Timing of individual actions over the life-cycle.

Therefore, following the Fisher Separation Theorem, optimal individual choices can be characterized by a two-step optimization problem: one where individuals choose educational investment to maximize discounted net-of-tax lifetime income and a second one where, for a given lifetime income, individuals choose their utility-maximizing intertemporal consumption profile by borrowing and lending in the perfect capital market. ${ }^{12}$

The timing of individual actions is depicted in Figure 1. In the first period of their life individuals choose their education. Human capital is supplied to the labor market in the second period. ${ }^{13}$ The government collects social security contributions and wage taxes at a rate $\tau^{s}$ and $\tau^{w}$, respectively, and individuals receive a net-of-tax wage income, $\left[1-\left(\tau^{s}+\tau^{w}\right)\right] w_{t} h_{t}$. Social security contributions are used to finance benefits for the current old generation whereas wage taxes finance public consumption. The middleaged generation invests its savings by buying land from the older generation and by participating in the international financial market. In the third period, individuals receive social security benefits. Formally, social security benefits in period $t+1, b_{t+1}$, depend on contributions made in period $t, c_{t}=\tau^{s} w_{t} h_{t}$, according to the formula

$$
b_{t+1}=(1+x) c_{t}
$$

where $x$ is the rate of return offered by the PAYG system. ${ }^{14}$ Finally, the older generation sells land to the current middle-aged generation. Recall, as there are no credit

\footnotetext{
${ }^{12}$ Thus, welfare gains of a transition to a fully-funded system cannot originate from capital market imperfections as is the case, e.g., in Börsch-Supan and Winter (2001).

${ }^{13}$ What is essential is that effective labor supply is endogenous in the second period of life. As an alternative to human capital formation we could assume endogenous time allocation between work and leisure.

${ }^{14}$ Without loss of generality we assume that pensions are not taxed. If pensions were taxed, then $b$ would be replaced by an after-tax pension.
} 
constraints or uncertainty, individuals maximize their utility when maximizing the net present value of resources available for consumption. Therefore, the individual maximization problem facing the members of a generation working in period $t$ and being young in period $t-1$ is: ${ }^{15}$

$$
\max _{e_{t-1}}\left(-e_{t-1}+\frac{1}{1+r}\left(1-\tau^{s}-\tau^{w}\right) e_{t-1}^{\beta} w_{t}+\frac{1}{(1+r)^{2}}(1+x) \tau^{s} e_{t-1}^{\beta} w_{t}\right)
$$

where the first term in brackets is the private cost of educational investment in period $t-1$, the second term is the after-tax wage income in period $t$ discounted to period $t-1$, and the third term is the social security benefit in period $t+1$, discounted to period $t-1$. The first-order condition becomes:

$$
-1+\frac{1}{1+r}\left(1-\tau^{s} \frac{r-x}{1+r}-\tau^{w}\right) \beta e_{t-1}^{\beta-1} w_{t}=0,
$$

which gives individual educational investment in period $t-1$ fixing wages. Using Eqs. (1) - (3) allows us to derive the level of investment in general equilibrium: ${ }^{16}$

$$
\widehat{e}_{t-1}=\left(\frac{1}{1+r}\left(1-\tau^{s} \frac{r-x}{1+r}-\tau^{w}\right) \beta \alpha_{H} A_{t}^{\frac{1}{1-\alpha_{K}}} N_{t}^{\frac{\alpha_{H}+\alpha_{K}-1}{1-\alpha_{K}}}\left(\frac{\alpha_{K}}{r}\right)^{\frac{\alpha_{K}}{1-\alpha_{K}}}\right)^{\frac{1-\alpha_{K}}{1-\alpha_{K}-\beta \alpha_{H}}} .
$$

Straightforward comparative statics yields:

$$
\left.\frac{\partial \widehat{e}_{t-1}(\cdot)}{\partial \tau^{s}}\right|_{r>x}<0
$$

The social security system discourages human capital investment if the rate of return under the PAYG system is lower than the interest rate. The rationale for this distortion is that lending in the international capital market for one period yields a rate of return $r$ while compulsory savings under the PAYG system earn a rate of return $x$. If the latter falls below the former, the PAYG system imposes an implicit tax on contributions equal to $\tau^{s} \frac{r-x}{1+r}$ which distorts human capital investment. Therefore, the combined tax burden imposed by the wage tax and the implicit social security tax reads $\tau:=\tau^{w}+$

\footnotetext{
${ }^{15}$ To simplify the exposition, trade in land does not enter the maximization problem. This is justified by the fact that land value is exogenous from each individual's perspective and, thus, does not affect educational investment. Furthermore, given the Fisher Separation Theorem, the saving decision does not have to be made explicit when analyzing optimal educational investment. It exclusively serves to implement the optimal life-cycle consumption plan.

${ }^{16}$ The rate of return provided by the PAYG system $x$ is exogenous for each individual, but endogenous for the economy. In the next section, it is shown that $x$ is a function of $\alpha_{H}, \alpha_{K}, \beta, g$ and $n$.
} 
$\tau^{s} \frac{r-x}{1+r}$. It is the implicit tax burden which is the source of inefficiency under the PAYG system. Further disincentive effects, e.g. due to intragenerational redistribution, are not ingeniously generated by a PAYG system and are not considered in the model.

\subsection{Steady-State Growth Path}

Human capital investment is independent of land price. For any sequence of land prices Eqs. (1), (2), (3), and (9) thus imply

$$
\begin{aligned}
\frac{h_{t}}{h_{t-1}} & =(1+g)^{\beta \gamma}(1+n)^{-\beta\left(1-\alpha_{K}-\alpha_{H}\right) \gamma}, \frac{H_{t}}{H_{t-1}}=(1+g)^{\beta \gamma}(1+n)^{\left(1-\alpha_{K}\right)(1-\beta) \gamma} \operatorname{and}(10) \\
\frac{R_{t}}{R_{t-1}} & =\frac{Y_{t}}{Y_{t-1}}=1+q
\end{aligned}
$$

where

$$
1+q:=(1+g)^{\gamma}(1+n)^{\alpha_{H}(1-\beta) \gamma} \text { and } \gamma:=\frac{1}{1-\alpha_{K}-\beta \alpha_{H}}>0
$$

The growth rate of production, $q$, depends only on the parameters related to technological progress, population growth and technology for production and human capital formation. It is independent of the wage tax rate, social security contribution rate or interest rate, which affect only the level of production but not its growth rate. Given by Eq. (10), individual human capital stock increases over time if $g \geq n$, or if $g$ is not much below $n$. If $g<<n$, then $h_{t}<h_{t-1}$ and human capital stock per worker would decrease over time. However, even in such an economy aggregate human capital and output would be still increasing.

Land price dynamics are captured by Eq. (5). Rearranging and using Eq. (10), it can be rewritten as

$$
\frac{1+r}{1+q} \frac{V_{t}}{R_{t}}=1+\frac{V_{t+1}}{R_{t+1}}
$$

As illustrated in Figure 2, a unique steady state $\frac{V^{*}}{R^{*}}$ exists if and only if $d\left(\frac{V_{t+1}}{R_{t+1}}\right) / d\left(\frac{V_{t}}{R_{t}}\right)$ exceeds unity. The $J$-schedule depicts all "price-dividend" ratios consistent with arbitrage behavior. Specifically, following Eq. (11), a positive and finite steady-state ratio of land price to land rent arises if and only if the interest rate exceeds the output growth rate, i.e. $r>q$. The steady state thus exhibits dynamic efficiency (Homburg, 1991 and Rhee, 


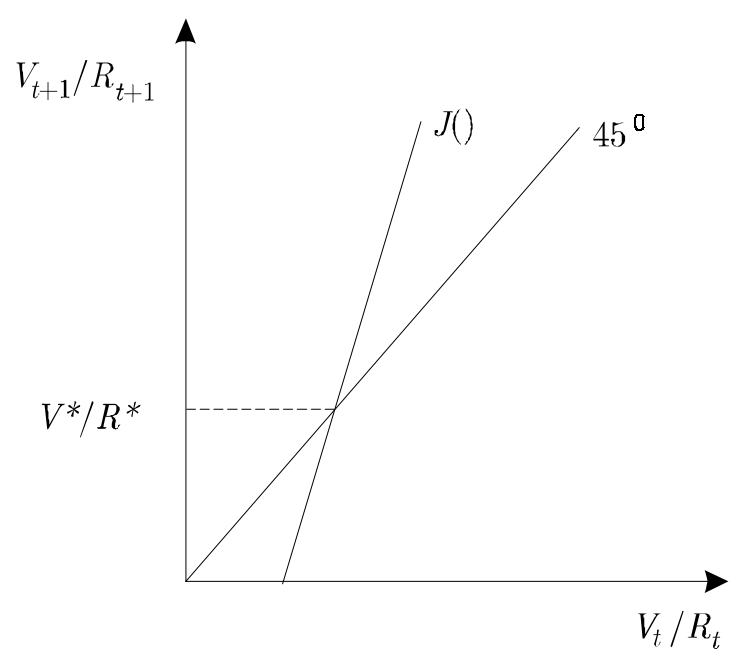

Figure 2: Steady State.

1991). ${ }^{17}$ Characterizing stability, for any value of $\frac{V_{t}}{R_{t}} \neq \frac{V^{*}}{R^{*}}$, the ratio does not converge to the steady state. Therefore, the only adjustment process consistent with perfect foresight is a jump to $\frac{V^{*}}{R^{*}}$ in the next period.

In a PAYG system $N_{t-1} b_{t}=N_{t} c_{t}$. Since $N_{t} c_{t}=\tau^{s} \alpha_{H} Y_{t}$, Eqs. (7) and (10) imply

$$
x=\frac{b_{t}}{c_{t-1}}-1=q
$$

The rate of return under the PAYG system equals the economy's growth rate (Aaron, 1966). Given dynamic efficiency, the PAYG system imposes an implicit tax on contributions equal to

$$
\tau^{s}>\tau^{s} \frac{r-q}{1+r}>0
$$

Using the land price equation (6) and the growth factor of land rents, the time path of land value is characterized by

$$
V_{t}=R_{t+1} \frac{1}{r-q}
$$

\footnotetext{
${ }^{17}$ The result is not specific to a Cobb-Douglas production function. With a more general production technology land continues to preclude dynamic inefficiency if land is essential, meaning that the income share of land does not vanish asymptotically (Rhee, 1991).
} 
The factor captures the effect of future output growth and discounting on current land value and is independent of the social security system. Any change in the social security tax rate in period $t$ is captured in the formula for land value through a jump in land rents in the subsequent period. Finally, the financial position of the country vis-a-vis the rest of the world must satisfy the transversality condition. When the net foreign assets of the economy in period $t$ are denoted by $F_{t}$, the transversality condition requires that $\lim _{T \rightarrow \infty}\left(\frac{1}{1+r}\right)^{T} F_{t+T+1}=0$ (Obstfeld and Rogoff, 1996). Here, the transversality condition is satisfied as the budget constraint is satisfied for each generation over its lifetime, and the growth rate of production as well as of land value is less than the interest rate.

\section{Social Security Reform}

Formally, we assume that social security tax rates are cut by proportion $\omega, \omega \in[0,1]$, from $\tau^{s}$ to $(1-\omega) \tau^{s}$. No reform occurs if $\omega=0$ whereas $\omega=1$ indicates a complete transition to a fully-funded system. Policy reform is announced and implemented at the beginning of the period $t^{*}$ before the current younger generation has decided on educational investment and the elderly have sold land to the middle-aged generation. ${ }^{18}$

Both the young and middle-aged benefit from social security reform. While the middleaged only enjoy a lower implicit tax on their contributions, the young also reap the benefits from less distorted educational investments. The preferences of the elderly are shaped by the relative size of two conflicting forces. On the one hand, if $\omega>0$ the elderly lose due to the cut in social security benefits. On the other hand, they receive an unexpected wealth increase. The increase of human capital investment of the current young and future generations and the implied lagged response of human capital supply increases land rents in all subsequent periods (starting in period $t^{*}+1$ ). Following Eq. (12), higher land rents generate an immediate jump in land value accruing to land owners; see Figure 3 assuming equal slopes of $H_{t}$ and $V_{t}$ for expositional simplicity. As the middle-aged have already made their investments in human capital, the value of production and wage tax revenue in the current period does not change, neither does the land rent accruing to the elderly

\footnotetext{
${ }^{18}$ Important for our result is that land is owned by the elderly at the time of policy announcement and implementation, which implies that both capital gains and reduced pension benefits accrue to current pensioners. Remarks on alternative timings of policy reform are briefly offered in the Conclusion.
} 


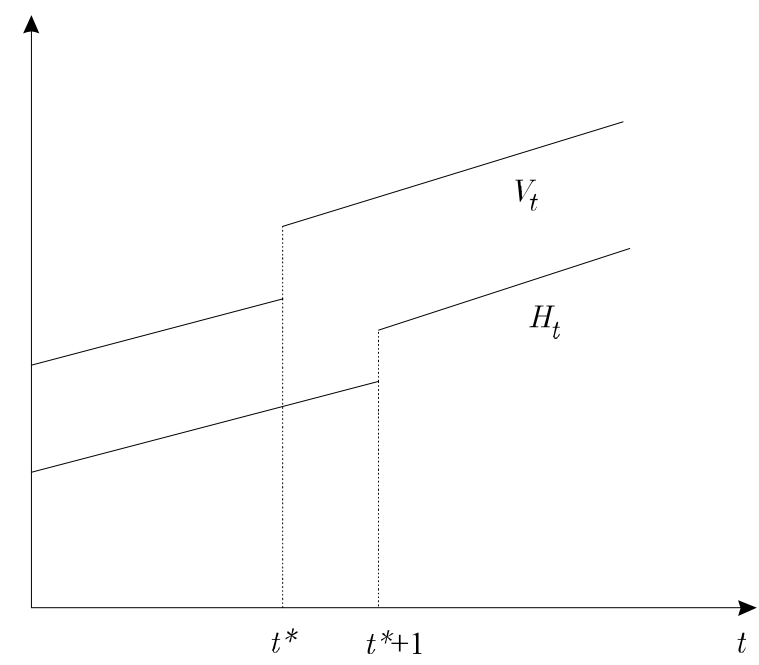

Figure 3: Effect of social security reform on $H_{t}$ and $V_{t}$.

before they sell the land. In order to allow for an economic interpretation, we measure these changes in relation to GDP. Denoting $B_{t}$ the size of the social security budget in period $t$, the social security reform is favored by the older generation if and only if

$$
\frac{\Delta B_{t}\left(\tau^{s}, \tau^{w}, \omega, \alpha_{H}, \alpha_{K}, \beta, g, n, r\right)}{Y_{t}}+\theta \frac{\Delta V_{t}\left(\tau^{s}, \tau^{w}, \omega, \alpha_{H}, \alpha_{K}, \beta, g, n, r\right)}{Y_{t}}>0
$$

where the parameter $\theta \in[0,1]$ represents the share of land owned by domestic pensioners. The first term captures the change in the PAYG benefits as a share of production and the second term indicates capital gain in land value for the elderly as a share of production. The first term is given by $\frac{\Delta B_{t}(\cdot)}{Y_{t}}=-\omega \tau^{s} \alpha_{H}$ and the second term is

$$
\theta \frac{\Delta V_{t}(\cdot)}{Y_{t}}=\theta\left(1-\alpha_{H}-\alpha_{K}\right) \frac{z}{1-z}\left[\left(\frac{\left(1-\tau^{s}(1-\omega)(1-z)-\tau^{w}\right)}{\left(1-\tau^{s}(1-z)-\tau^{w}\right)}\right)^{\gamma \beta \alpha_{H}}-1\right]
$$

where

$$
z:=\frac{1+q}{1+r}
$$

is the ratio between the gross rate of return offered by the PAYG system and the gross rate of return offered by the financial market. With dynamic efficiency, $z<1$.

$\theta>0$ proves to be a necessary condition for a Pareto-improving reform. There is nothing inherent in the condition (13) to rule out the possibility of a social security reform 
benefiting the old. However, proving this requires either characterizing the circumstances under which the condition is satisfied and proving that there are values satisfying these circumstances, or providing an example of such parameter values. In this paper, political feasibility is proved directly by providing such an example. As a baseline scenario for our numerical analysis we choose:

\begin{tabular}{cccccccc}
\hline$\alpha_{H}$ & $\alpha_{K}$ & $\beta$ & $z$ & $\tau^{s}$ & $\tau^{w}$ & $\theta$ & $\omega$ \\
\hline 0.6 & 0.1 & 0.8 & 0.9 & 0.1 & 0.5 & 1 & 0.1 \\
\hline
\end{tabular}

The value of $z$ is chosen so that it corresponds closely to an annual growth rate of productivity of 1 percent and an interest rate of 4 percent when the distance between two generations is 20 years, and there is no population growth. The implied growth rate of GDP is 3.5 percent.

The social security tax rate is 0.1 which proves to be a conservative estimate for $\tau^{s} \cdot{ }^{19}$ In order to capture the distortionary effect of taxes other than wage taxes such as consumption and capital income taxes, we choose $\tau^{w}=0.5$ (see Mendoza et al., 1994). Simulations are performed for $\omega=0.1$.

Proposition 1 An intragenerationally fair PAYG system may allow for a transition towards a fully-funded system favored by the elderly if there is intergenerational trade in land.

Proof. Condition (13) holds with the specification $\alpha_{H}=0.6, \alpha_{K}=0.1, \beta=0.8$, $\tau^{s}=0.1, \tau^{w}=0.5, \omega=0.1, \theta=1, z=0.9$.

Proposition 1 is sufficient to prove the existence of a Pareto-improving transition, but not to evaluate its plausibility with other parameter values. To evaluate the plausibility of such a transition path, we analyze different combinations of $\alpha_{H}, \alpha_{K}$ and $\beta$ which satisfy condition (13) keeping $z, \tau^{s}$ and $\tau^{w}$ at the benchmark level. By fixing $z$, we fix the ratio between the growth rate of the economy and the interest rate, with $z<1$ implying that the economy is dynamically efficient with all tested combinations.

Proposition 2 An intragenerationally fair PAYG system may allow for a transition towards a fully-funded system favored by the elderly also if there is no adjustable physical capital, but the only factors of production are human capital and the fixed factor.

\footnotetext{
${ }^{19}$ For instance, in 2002 the U.S. social security tax rate amounts to 12.4 percent and in Germany it is slightly below 20 percent.
} 


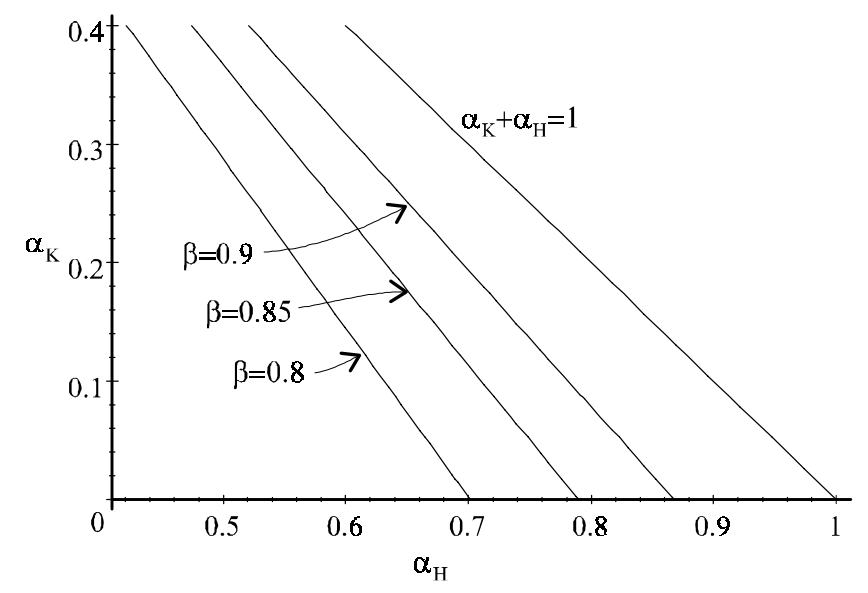

Figure 4: Scope for Pareto-improvement in $\left(\alpha_{H}, \alpha_{K}\right)$ space.

Proof. Condition (13) holds with the specification $\alpha_{H}=0.6, \alpha_{K}=0, \beta=0.8$, $\tau^{s}=0.1, \tau^{w}=0.5, \omega=0.1, \theta=1, z=0.9$.

The result of Proposition 2 guarantees that our result does not rely on the presence of perfectly mobile and adjustable physical capital. This result even holds if some land is in foreign ownership. The critical share of land ownership in the proof above can be computed as $\theta \approx 0.88$.

Figure 4 depicts $\left(\alpha_{H}, \alpha_{K}\right)$ combinations for varying values of $\beta$ for which the elderly benefit from social security reform (parameter combinations below the respective lines). The upper line represents all combinations which add up to unity indicating a positive factor share of land for all values below the line. The set of parameter values allowing for Pareto-improvement expands as $\beta$ increases. Human capital investment becomes more sensitive to changes in the net wage for higher values of $\beta$. Given complementarity in production, this positively affects future productivity of land and thus the magnitude of the capitalization effect. Furthermore, the scope for Pareto-improvement widens if $\alpha_{K}$ is reduced. Intuitively, fixing $\alpha_{H}$ a lower capital income share increases the factor share of land. This magnifies the fraction of future efficiency effects of pension reform capitalized in current land price.

Figure 5 displays $\left(\alpha_{K}, \beta\right)$ combinations for varying values of $z$ for which the elderly benefit from pension reform (parameter combinations above the respective curves). A reform becomes more likely Pareto-improving for higher (lower) values of $\beta\left(\alpha_{K}\right)$ - the 


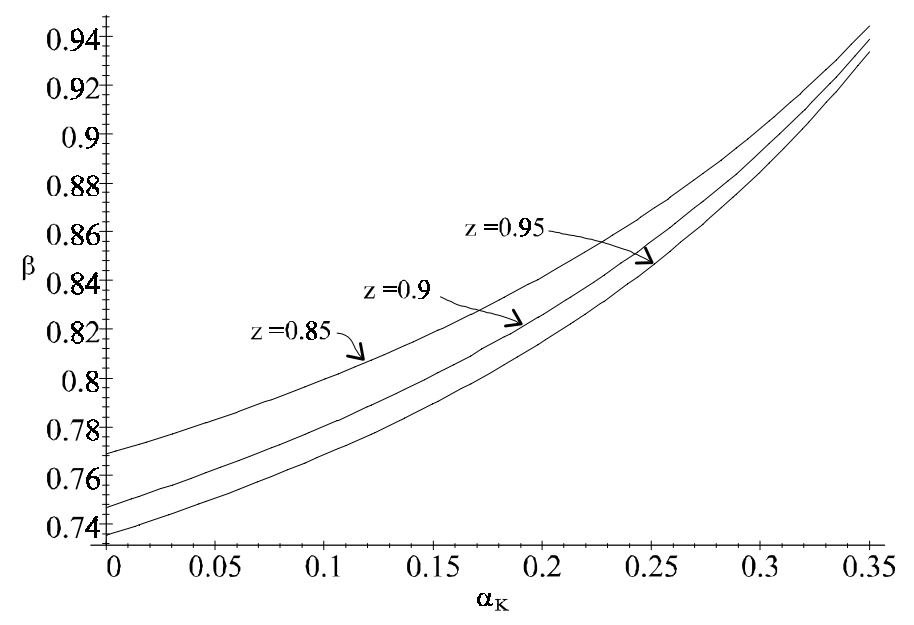

Figure 5: Scope for Pareto-improvement in $\left(\alpha_{K}, \beta\right)$ space varying $z$.

intuition presented in the last paragraph equally applies here. The variable $z<1$ measures the magnitude of the implicit tax rate imposed by PAYG. One might therefore expect that a lower value of $z$ eases search for reform proposals benefiting the elderly. As can be inferred from Figure 5 the opposite holds true for our parameter baseline. This is because the positive effect is dominated by stronger discounting of future productivity effects as $z$ reduces (Eq. (12)), which diminishes the scope of the asset price channel to compensate the elderly.

The impact of wage taxation, $\tau^{w}$, on the well-being of the elderly during pension reform is depicted in Figure 6. Again, all parameter values above the respective curves yield a Pareto-improving reform. Confirming intuition, the figure reveals a positive relation between pension reform proposals supported by the elderly and the level of general wage taxation. A less pronounced general tax rate reduces the excess-burden in the economy (convex in the overall level of taxation). The positive efficiency effects due to partially abolishing the PAYG system are consequently diminished and so is the capitalization effect.

Propositions 1 and 2 prove the existence of a marginal PAYG reform benefiting the elderly $(\omega=0.1)$. However, even with a full transition, intergenerational trade in land may be sufficient to compensate current pensioners for lost benefits.

Corollary 1 Social security reform may be Pareto-improving even with a full transition 


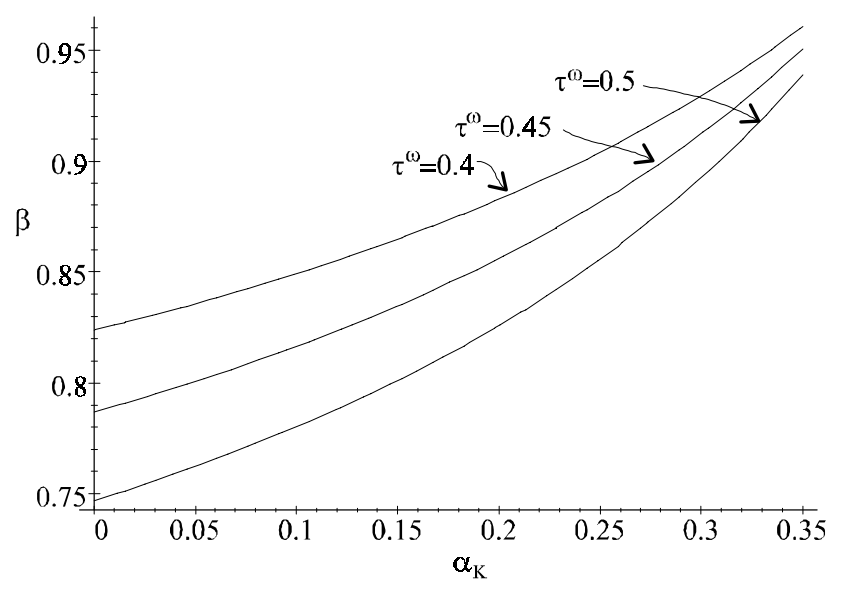

Figure 6: Scope for Pareto-improvement in $\left(\alpha_{K}, \beta\right)$ space varying $\tau^{\omega}$.

to a fully funded system.

Proof. Condition (13) holds with the specification $\alpha_{H}=0.6, \alpha_{K}=0.1, \beta=0.8$, $\tau^{s}=0.1, \tau^{w}=0.5, \omega=1, \theta=1$, and $z=0.9$.

The presence of technological progress or population growth is not necessary to implement PAYG reform, as Proposition 1 implies also that:

Corollary 2 Reducing the social security tax rate may result in a Pareto improvement even without technological progress or population growth.

Proof. With $g=0$ and $n=0$, any value $z<1$ can be attained by varying $r$.

Given by Corollary 2, a social security reform may exist which is supported by the elderly even in a stationary and dynamically efficient economy with an intragenerationallyfair PAYG system.

Finally, we should notice that there is a further welfare gain from increased future public expenditures. As the wage tax rate is kept constant, increased production implies increased tax revenue as a result of a decreasing social security tax rate. Therefore, finding a reform proposal supported by pensioners would be an easier task if we were to fix the revenue requirement for public expenditures, instead of fixing the wage tax rate used to finance them. 


\section{The Rise and Fall of the PAYG System}

Our analysis in the previous section raises a legitimate question: If the elimination of a PAYG system could be a Pareto improvement, why would such a system exist? It is not plausible that a PAYG system would have been implemented in the first place if it did not benefit the older generation at that time. The creation of a PAYG system could be explained, outside our model, by arguments like the inability of the poor to save for their retirement in the 19th century. However, even our basic model captures some obvious candidates for why the PAYG system could have benefited the elderly in the first place, but lost its appeal subsequently. One such candidate is unequal distribution of land ownership. The poor, older citizens without assets would favor a PAYG system, as they are not hurt by the efficiency loss capitalized in land value. Therefore, an increasing middle-class with widespread stock ownership might contribute to the eroded popularity of the PAYG system among the elderly. Another obvious candidate is the secular increase in other public expenditures. An increased tax burden implies higher distortions, and increases the cost of maintaining a PAYG system. As the increase in the welfare state during the 20th century was not anticipated when the social security system was introduced, the elderly could have supported its introduction then, but now benefit from its abolishment even if nothing else than the general wage tax rate had changed. We summarize this argument as

Proposition 3 If the elderly are indifferent between $\tau^{s}$ and $(1-\omega) \tau^{s}, \omega>0$, with a given wage tax rate $\widetilde{\tau}^{w}$, then they would strictly prefer $(1-\omega) \tau^{s}$ with all $\tau^{w}>\widetilde{\tau}^{w}$.

Proof. The elderly being indifferent to a reduction of social security tax rate by $\omega \tau^{s}, \omega>0$, implies that $\theta>0$, as otherwise the elderly would always strictly prefer a higher social security tax rate. With wage tax rate $\widetilde{\tau}^{w}$,

$$
\theta\left(1-\alpha_{H}-\alpha_{K}\right) \frac{z}{1-z}\left[\left(\frac{\left(1-\tau^{s}(1-\omega)(1-z)-\tau^{w}\right)}{\left(1-\tau^{s}(1-z)-\tau^{w}\right)}\right)^{\gamma \beta \alpha_{H}}-1\right]-\omega \tau^{s} \alpha_{H}=0 .
$$

Differentiation of the left-hand side with respect to $\tau^{w}$ yields

$$
\theta \gamma \beta \alpha_{H}\left(1-\alpha_{H}-\alpha_{K}\right) \frac{z}{1-z}\left(\frac{\left(1-\tau^{s}(1-\omega)(1-z)-\tau^{w}\right)}{\left(1-\tau^{s}(1-z)-\tau^{w}\right)}\right)^{\gamma \beta \alpha_{H}-1} \frac{\tau^{s} \omega(1-z)}{\left(1-\tau^{s}(1-z)-\tau^{w}\right)^{2}} .
$$


As this is positive with any $\omega>0$, an increase in the wage tax rate is sufficient to induce the elderly to favor a cut in the social security tax rate.

As a corollary, Proposition 3 implies:

Corollary 3 If the elderly are currently indifferent between maintaining the current social security system or eliminating it, they would have favored its establishment with any given lower level of wage tax rate.

In addition to changes in the wage tax rate, changes in technological progress, population growth rate as well as the interest rate can affect the attractiveness of social security reform through their effects on $z$. Even though we have not been able to determine that Eq. (14) would be monotonic in $z$, we have:

Proposition 4 An increase in the level of technological progress has qualitatively the same effect on the attractiveness of social security reform as an increase in the population growth rate or a reduction in the interest rate.

Proof. Follows from definitions of $z$ and $q$.

Our numerical analysis suggests that increasing $z$ widens the prospects of Paretoimproving pension reform through diminished discounting. This is a surprising finding, as it implies that a reduction in the population growth rate (lower $z$ ), and therefore an increase in the dependency ratio, would actually reduce the scope for a Pareto-improving reduction in the social security tax rate. Given our baseline, demographic change affects asset prices in a different way than previous literature has focused on. Therein the higher rate of return under a fully-funded system might partially be eroded by population aging since future pensioners have to sell financial assets to a smaller generation of young investors when liquidating their portfolios; see Abel (2001) and Poterba (2001) for a critical evaluation of the "meltdown" hypothesis. In the present paper, equilibrium land price in each period is not directly affected by a change in the ratio of the number of suppliers to demanders. Instead, negative demographic shocks reduce asset returns in each subsequent period due to lower steady state growth which immediately capitalizes in asset prices. 


\section{Conclusion}

In this paper, we demonstrate that the scope for Pareto improvements in social security systems is wider than previous literature suggests. In earlier literature, the Pareto improvements in PAYG systems rely on externalities or intragenerational redistribution. However, both absent, Fenge (1995) and Brunner (1996) argue that a Pareto improving transition from a PAYG system is not possible. We show that this might not be the case in an economy with a fixed factor of production, here labeled as land. As land value captures future land rents, intergenerational trade in land allows the pensioners of the transition generation to participate in the benefits of reducing the social security tax rate. Even a PAYG system without distortions due to intragenerational redistribution may allow for a Pareto improvement, especially if the taxation to finance other public expenditures has increased after the PAYG system was created.

There are important caveats when drawing policy implications. First of all, the simulations are suggestive and are not meant to be calibrated to a specific economy. Secondly, an asset value effect may also introduce unexpected inefficiencies. Poutvaara (forthcoming) demonstrates in a model without social security that the older generation may voluntarily provide an inefficiently high amount of public education for the younger generation in order to benefit through higher land prices. A more policy-oriented analysis should calibrate the factor shares of fixed and adjustable physical capital, as well as the production function for human capital. As the effects of the PAYG system may depend crucially on other taxes, it would be desirable to replicate the essential features of the tax system in numerical analysis. This exercise, as well as modeling asset price effects through a revaluation of existing physical capital (as common in tax reform analysis; see e.g. Altig et al., 2001) is left to future research. Applied to social security reform, the last extension is likely to strengthen our paper's findings since it opens up an additional intergenerational link through which the current elderly have a stake in future productivity gains.

Independently of whether the actual economies would allow for a Pareto improving reform or not, our paper offers several policy conclusions. Increased tax burden moves the interest of asset-owning retirees closer to those of working cohorts, while expected reductions in the size of the public sector could close a window of opportunity to reform 
social security systems. Furthermore, our paper suggests that taxing capital gains above the normal rate of return could be used to finance efficiency-improving reforms boosting future productivity. ${ }^{20}$ Such compensation mechanism would be needed if the elderly do not own the land, or if the social security reform is announced prior to its implementation. In the latter case benefits and costs of the reform accrue to different generations in the absence of capital gains taxation. As a final policy conclusion, voting behavior of the elderly depends on how land ownership is distributed amongst them. Even if all citizens had identical productivity, they may have different voting incentives if they have unequal amounts of land, say due to differing amounts of inherited wealth. The possibility of reforming social security may arise when an increased number of the elderly become members of the capitalist class owning productive assets. As reported in Poterba et al. (2001) such development has indeed taken place during the last decades in the U.S. On the other hand, international portfolio diversification may render reforming social security system more difficult. This would support investing private pension funds in the domestic market, in order to increase the stake that the elderly have in future efficiency gains.

\section{Appendix: Social Security Reform with Heteroge- neous Population}

In this appendix, we analyze the conditions under which the results from Section 3 hold in an economy in which people differ in their ability and in their asset ownership. Let us divide the working population in period $t$ into $I$ groups $(i=1, . ., I)$, so that individuals in any group $(t, i)$ share the same ability and asset ownership characteristics. We define ability as individual ability to absorb and effectively utilize investment in human capital. A member of group $(t, i)$ being a worker in period $t$ has ability $\infty>a_{t, i}>0$. Instead of Eq. (2), the production function for human capital is now

$$
h_{t, i}=a_{t, i} e_{t-1, i}^{\beta}
$$

in which $e_{t-1, i}$ is investment in human capital in period $t-1$ by individuals belonging

\footnotetext{
${ }^{20}$ As a first step in this direction, asset price effects (due to a fixed factor) induced by tax reform are considered in Keuschnigg (1994). However, a rationale for capital gains taxation to solve intergenerational conflict is not developed therein.
} 
to the ability group $(t, i)$. To reflect the empirical fact that workers belonging to highincome groups often have more expensive education, we assume that the cost of creating human capital stock $a_{t, i} e_{t-1, i}^{\beta}$ equals $a_{t, i} e_{t-1, i}$. The number of workers belonging to the ability class $(t, i)$ is $n_{t, i}$. We normalize the measure of ability so that the average ability is unity in each period, implying that $\sum_{i} n_{t, i} a_{t, i}=N_{t}$. Replacing $e_{t-1}$ by $e_{t-1, i}$ and the stock of human capital $e_{t-1}^{\beta}$ by $a_{t, i} e_{t-1, i}^{\beta}$ in the individual maximization problem (8) and solving the first-order conditions for different ability classes $i$ yields identical investments in human capital $\widehat{e}_{t-1, i}$. Through adopting this normalization, this translates into an aggregate stock of human capital in the economy and factor prices both of which are identical to the case without heterogeneity.

What remains to be analyzed are the welfare effects of a social security reform for different ability classes. Subsequently, we denote the share of domestically-owned land held in period $t$ by the elderly members of the ability class $(t-1, i)$ by $\psi_{t-1, i}$. Corresponding to Section 3, we can now derive the condition under which social security reform benefits the members of this ability class:

$\frac{n_{t-1, i} a_{t-1, i}}{N_{t-1}} \frac{\Delta B_{t}\left(\tau^{s}, \tau^{w}, \omega, \alpha_{H}, \alpha_{K}, \beta, g, n, r\right)}{Y_{t}}+\psi_{t-1, i} \theta \frac{\Delta V_{t}\left(\tau^{s}, \tau^{w}, \omega, \alpha_{H}, \alpha_{K}, \beta, g, n, r\right)}{Y_{t}}>0$,

in which $\frac{n_{t-1, i} a_{t-1, i}}{N_{t-1}}$ denotes the share of social security benefits belonging to ability class $(t-1, i)$. If $\frac{n_{t-1, i} a_{t-1, i}}{N_{t-1}}=\psi_{t-1, i}$, the results from Section 3 can be generalized to an economy with a heterogeneous population. In this case, land ownership is distributed in the same way as wage income and, importantly, social security benefits.

Therefore, what is crucial in analyzing the feasibility of a Pareto-improvement is $\min _{i}\left(\frac{\psi_{t-1, i}}{n_{t-1, i} a_{t-1, i} / N_{t-1}} \theta\right)$, which is the ratio of the share of land owned by the members of ability class $(t-1, i)$ to its share of wage income in period $t-1$, which is again equal to its share of social security benefits in period $t$. Let us denote the minimum value of these ratios in period $t$ by $\lambda_{t-1}$. If all land is owned domestically and asset ownership is perfectly correlated with wage income, then $\lambda_{t-1}=1$. If land ownership were to be distributed either less or more equally than wage income and entitlement to social security benefits, then this disparity would reduce scope for a Pareto-improvement in the absence of capital gains taxation above the normal rate of return on fixed asset holdings. For instance, 
starting at the parameter baseline, the critical value for $\lambda_{t-1}$ becomes $\approx 0.95 .^{21}$ Disparity is not allowed to be too large in order to achieve a Pareto-improvement for each ability class. If $\lambda_{t-1}$ drops below the threshold level, there is demand for capital gains taxation in order to redistribute the aggregate increments in land value (exceeding the reduction in the social security budget) intragenerationally to achieve Pareto-improvement for all households.

\section{References}

[1] Aaron, H.J. (1966), "The Social Insurance Paradox", Canadian Journal of Economics and Political Science, 33, 371-374.

[2] Abel, A. (2001), "Will Bequests Attenuate the Predicted Meltdown in Stock Prices When Baby Boomers Retire?", Review of Economics and Statistics, 83, 589-595.

[3] Altig, D., A. Auerbach, L.J. Kotlikoff, K.A. Smetters, and J. Walliser (2001), "Simulating Fundamental Tax Reform in the United States", American Economic Review, 91, 574-595.

[4] Belan, P., Ph. Michel, and P. Pestieau (1998), "Pareto-Improving Social Security Reform", Geneva Papers on Risk and Insurance Theory, 23, 119-125.

[5] Boadway, R. and D. Wildasin (1989), "A Median Voter Model of Social Security", International Economic Review, 30, 307-328.

[6] Börsch-Supan, A. and J. Winter (2001), "Population Aging, Savings Behavior and Capital Markets", Working Paper No. 8561, National Bureau of Economic Research, Cambridge.

[7] Breyer, F. (1989), "On the Intergenerational Pareto Efficiency of Pay-as-you-go Financed Pension Systems", Journal of Institutional and Theoretical Economics, 145, 643-658.

\footnotetext{
${ }^{21}$ Increased popularity of defined contribution plans, as documented by Poterba et al. (2001), has probably increased the value of $\lambda$ among those retirees participating.
} 
[8] Brunner, J.K. (1996), "Transition from a Pay-as-you-go to a Fully Funded System: The Case of Differing Individuals and Intragenerational Fairness", Journal of Public Economics, 60, 131-146.

[9] Cooley, T.F. and J. Soares (1999a), "A Positive Theory of Social Security Based On Reputation", Journal of Political Economy, 107, 135-160.

[10] Cooley, T.F. and J. Soares (1999b), "Privatizing Social Security", Review of Economic Dynamics, 2, 731-755.

[11] Corsetti, G. and K. Schmidt-Hebbel (1997), "Pension Reform and Growth", in: S. Valdes-Prieto (ed.), The Economics of Pensions: Principles, Policies, and International Experience, Cambridge University Press, Cambridge.

[12] Cremer, H. and P. Pestieau (2002), "The Double Dividend of Postponing Retirement," mimeo, University of Liège.

[13] Diamond, P.A. (1996), "Proposals to Restructure Social Security", Journal of Economic Perspectives, 10, 67-88.

[14] Feldstein, M. (1996), "The Missing Piece in Policy Analysis: Social Security Reform", American Economic Review, 86, 1-14.

[15] Feldstein, M. and A. Samwick (1998), "The Transition Path to Privatizing Social Security", in: M. Feldstein (ed.), Privatizing Social Security, The University of Chicago Press, Chicago, 215-264.

[16] Fenge, R. (1995), "Pareto-Efficiency of the Pay-as-you-go Pension System with Intragenerational Fairness", Finanzarchiv, 52, 357-364.

[17] Gordon, R.H. and A.L. Bovenberg (1996), "Why is Capital so Immobile Internationally? Possible Explanations and Implications for Capital Income Taxation", American Economic Review, 86, 1057-1075.

[18] Hansson, I. and C. Stuart (1989), "Social Security as Trade among Living Generations", American Economic Review, 79, 1182-1195. 
[19] Homburg, S. (1990), "The Efficiency of Unfunded Pension Schemes", Journal of Theoretical and Institutional Economics, 146, 630-647.

[20] Homburg, S. (1991), "Interest and Growth in an Economy with Land", Canadian Journal of Economics, 24, 450-459.

[21] İmrohoroğlu, A., S. İmrohoroğlu, and D.H. Joines, "Social Security in an Overlapping Generations Economy with Land", Review of Economic Dynamics, 2, 638-665.

[22] Keuschnigg, C. (1994), "Dynamic Tax Incidence and Intergenerationally Neutral Tax Reform", European Economic Review, 38, 343-366.

[23] Kotlikoff, L.J. (1998), "Simulating the Privatization of Social Security in General Equilibrium", in: M. Feldstein (ed.), Privatizing Social Security, The University of Chicago Press, Chicago, 265-312.

[24] Laitner, J. (2000), "Social Security Reform and National Wealth", Scandinavian Journal of Economics, 102, 349-371.

[25] Mendoza, E.G., A. Razin, and L.L. Tesar (1994), "Effective Tax Rates in Macroeconomics - Cross-Country Estimates of Tax Rates on Factor Incomes and Consumption", Journal of Monetary Economics, 34, 297-323.

[26] Miles, D. and A. Timmermann (1999), "Risk Sharing and Transition Costs in the Reform of Pension Systems in Europe", Economic Policy, 29, 253-286.

[27] Obstfeld, M. and K. Rogoff (1996), Foundations of International Macroeconomics, MIT Press, Cambridge, Massachusetts.

[28] Poterba, J.M. (2001), "Demographic Structure and Asset Returns", Review of Economics and Statistics, 83, 565-584.

[29] Poterba, J.M. , S.F. Venti, and D.A. Wise (2001), "The Transition to Personal Accounts and Increasing Retirement Wealth: Macro and Micro Evidence", Working Paper No. 8610, National Bureau of Economic Research, Cambridge. 
[30] Poutvaara, P. (forthcoming), "Gerontocracy Revisited: Unilateral Transfer to the Young May Benefit the Middle-aged." Journal of Public Economics.

[31] Rhee, Ch. (1991), "Dynamic Efficiency in an Economy with Land", Review of Economic Studies, 58, 791-797.

[32] Roberts, M.A. (2001), "Funding the Transition From Pay-As-You-Go Pensions by Taxing Capital Gains on Land", Working Paper No. 2001-13, European Policy Research Unit, University of Copenhagen.

[33] Sinn, H.W. (2000), "Why a Funded Pension System is Useful and Why It is Not Useful", International Tax and Public Finance, 7, 389-410.

[34] Tirole, J. (1985), "Asset Bubbles and Overlapping Generations", Econometrica, 53, $1499-1528$.

[35] Verbon, H.A.A. (1989), "Conversion Policies for Public Pension Plans in a Small Open Economy", in B.A. Gustafsson and N.A. Klevmarken (eds.), The Political Economy of Social Security, Elsevier Science (North-Holland), Amsterdam, 83-95. 


\section{CESifo Working Paper Series}

(for full list see www.cesifo.de)

728 Erik Leertouwer and Jakob de Haan, How to Use Indicators for 'Corporatism' in Empirical Applications, May 2002

729 Matthias Wrede, Small States, Large Unitary States and Federations, May 2002

730 Christian Schultz, Transparency and Tacit Collusion in a Differentiated Market, May 2002

731 Volker Grossmann, Income Inequality, Voting Over the Size of Public Consumption, and Growth, May 2002

$732 \mathrm{Yu}-\mathrm{Fu}$ Chen and Michael Funke, Working Time and Employment under Uncertainty, May 2002

733 Kjell Erik Lommerud, Odd Rune Straume, and Lars Sørgard, Downstream Merger with Oligopolistic Input Suppliers, May 2002

734 Saku Aura, Does the Balance of Power Within a Family Matter? The Case of the Retirement Equity Act, May 2002

735 Sandro Brusco and Fausto Panunzi, Reallocation of Corporate Resources and Managerial Incentives in Internal Capital Markets, May 2002

736 Stefan Napel and Mika Widgrén, Strategic Power Revisited, May 2002

737 Martin W. Cripps, Godfrey Keller, and Sven Rady, Strategic Experimentation: The Case of Poisson Bandits, May 2002

738 Pierre André Chiappori and Bernard Salanié, Testing Contract Theory: A Survey of Some Recent Work, June 2002

739 Robert J. Gary-Bobo and Sophie Larribeau, A Structural Econometric Model of Price Discrimination in the Mortgage Lending Industry, June 2002

740 Laurent Linnemer, When Backward Integration by a Dominant Firm Improves Welfare, June 2002

741 Gebhard Kirchgässner and Friedrich Schneider, On the Political Economy of Environmental Policy, June 2002

742 Christian Keuschnigg and Soren Bo Nielsen, Start-ups, Venture Capitalits, and the Capital Gains Tax, June 2002

743 Robert Fenge, Silke Uebelmesser, and Martin Werding, Second-best Properties of Implicit Social Security Taxes: Theory and Evidence, June 2002 
744 Wendell Fleming and Jerome Stein, Stochastic Optimal Control, International Finance and Debt, June 2002

745 Gene M. Grossman, The Distribution of Talent and the Pattern and Consequences of International Trade, June 2002

746 Oleksiy Ivaschenko, Growth and Inequality: Evidence from Transitional Economies, June 2002

747 Burkhard Heer, Should Unemployment Benefits be Related to Previous Earnings?, July 2002

748 Bas van Aarle, Giovanni Di Bartolomeo, Jacob Engwerda, and Joseph Plasmans, Staying Together or Breaking Apart: Policy-makers' Endogenous Coalitions Formation in the European Economic and Monetary Union, July 2002

749 Hans Gersbach, Democratic Mechanisms: Double Majority Rules and Flexible Agenda Costs, July 2002

750 Bruno S. Frey and Stephan Meier, Pro-Social Behavior, Reciprocity or Both?, July 2002

751 Jonas Agell and Helge Bennmarker, Wage Policy and Endogenous Wage Rigidity: A Representative View From the Inside, July 2002

752 Edward Castronova, On Virtual Economies, July 2002

753 Rebecca M. Blank, U.S. Welfare Reform: What's Relevant for Europe?, July 2002

754 Ruslan Lukach and Joseph Plasmans, Measuring Knowledge Spillovers Using Patent Citations: Evidence from the Belgian Firm's Data, July 2002

755 Aaron Tornell and Frank Westermann, Boom-Bust Cycles in Middle Income Countries: Facts and Explanation, July 2002

756 Jan K. Brueckner, Internalization of Airport Congestion: A Network Analysis, July 2002

757 Lawrence M. Kahn, The Impact of Wage-Setting Institutions on the Incidence of Public Employment in the OECD: 1960-98, July 2002

758 Sijbren Cnossen, Tax Policy in the European Union, August 2002

759 Chandima Mendis, External Shocks and Banking Crises in Developing Countries: Does the Exchange Rate Regime Matter?, August 2002

760 Bruno S. Frey and Lars P. Feld, Deterrence and Morale in Taxation: An Empirical Analysis, August 2002

761 Lars Calmfors and Åsa Johansson, Nominal Wage Flexibility, Wage Indexation and Monetary Union, August 2002

762 Alexander R. W. Robson and Stergios Skaperdas, Costly Enforcement of Property Rights and the Coase Theorem, August 2002 
763 Horst Raff, Preferential Trade Agreements and Tax Competition for Foreign Direct Investment, August 2002

764 Alex Cukierman and V. Anton Muscatelli, Do Central Banks have Precautionary Demands for Expansions and for Price Stability? - Theory and Evidence, August 2002

765 Giovanni Peri, Knowledge Flows and Knowledge Externalities, August 2002

766 Daniel Friedman and Nirvikar Singh, Equilibrium Vengeance, August 2002

767 Sam Bucovetsky and Michael Smart, The Efficiency Consequences of Local Revenue Equalization: Tax Competition and Tax Distortions, August 2002

768 Tapio Palokangas, International Labour Market Regulation and Economic Growth with Creative Destruction, August 2002

769 Rudi Dornbusch, The New International Architecture, September 2002

770 Hans-Werner Sinn, Weber's Law and the Biological Evolution of Risk Preferences: The Selective Dominance of the Logarithmic Utility Function, September 2002

771 Thomas Mayer, The Macroeconomic Loss Function: A Critical Note, September 2002

772 Seppo Honkapohja and Kaushik Mitra, Learning Stability in Economies with Heterogenous Agents, September 2002

773 David Laidler, Inflation Targets Versus International Monetary Integration - A Canadian Perspective, September 2002

774 Morten I. Lau, Panu Poutvaara, and Andreas Wagener, The Dynamic Cost of the Draft, September 2002

775 Steven Brakman, Harry Garretsen, and Charles van Marrewijk, Locational Competition and Agglomeration: The Role of Government Spending, September 2002

776 Anke S. Kessler and Christoph Lülfesmann, The Theory of Human Capital Revisited: On the Interaction of General and Specific Investments, September 2002

777 Kjell Erik Lommerud, Frode Meland and Lars Sørgard, Unionized Oligopoly, Trade Liberalization and Location Choice, September 2002

778 Antonio Merlo and François Ortalo-Magné, Bargaining over Residential Real Estate: Evidence from England, September 2002

$779 \mathrm{Yu}-\mathrm{Fu}$ Chen and Michael Funke, Exchange Rate Uncertainty and Labour Market Adjustment under Fixed and Flexible Exchange Rates, September 2002

780 Michael S. Michael, International Migration, Income Taxes and Transfers: A Welfare Analysis, September 2002 
781 Clemens Fuest and Alfons Weichenrieder, Tax Competition and Profit Shifting: On the Relationship between Personal and Corporate Tax Rates, October 2002

782 Jan Bouckaert and Hans Degryse, Softening Competition by Enhancing Entry: An Example from the Banking Industry, October 2002

783 Johann K. Brunner and Susanne Pech, Adverse Selection in the Annuity Market with Sequential and Simultaneous Insurance Demand, October 2002

784 Gregory D. Hess and Eduard Pelz, The Economic Welfare Cost of Conflict: An Empirical Assessment, October 2002

785 Jan Erik Askildsen, Uwe Jirjahn, and Stephen C. Smith, Works Councils and Environmental Investment: Theory and Evidence from German Panel Data, October 2002

786 Geir H. Bjønnes, Dagfinn Rime, and Haakon O. Aa. Solheim, Volume and Volatility in the FX-Market: Does it matter who you are?, October 2002

787 John Evans and John Fingleton, Entry Regulation and the Influence of an Incumbent Special Interest Group, October 2002

788 Wolfgang Ochel, International Comparisons and Transfer of Labour Market Institutions, October 2002

789 B. Gabriela Mundaca, Moral Hazard Effects of Bailing out under Asymmetric Information, October 2002

790 Gene M. Grossman and Edwin L.-C. Lai, International Protection of Intellectual Property, October 2002

791 John Hassler, José V. Rodriguez Mora, Kjetil Storesletten, and Fabrizio Zilibotti, A Positive Theory of Geographic Mobility and Social Insurance, October 2002

792 Paul De Grauwe and Marianna Grimaldi, The Exchange Rate in a Model with Heterogeneous Agents and Transactions Costs, October 2002

793 Guido Friebel and Mariassunta Giannetti, Fighting for Talent: Risk-shifting, Corporate Volatility, and Organizational Change, October 2002

794 Jan Erik Askildsen, Badi H. Baltagi, and Tor Helge Holmås, Will Increased Wages Reduce Shortage of Nurses? A Panel Data Analysis of Nurses' Labour Supply, October 2002

795 Marko Köthenbürger and Panu Poutvaara, Social Security Reform and Intergenerational Trade: Is there Scope for a Pareto-Improvement?, October 2002 